\title{
New Horizons for the Rule of Law Within the EU
}

\author{
Koen Lenaerts*
}

\section{A. Introduction}

The purpose of this Article for this special issue of the German Law Journal is to argue that "integration through the rule of law" defines what the European Union stands for. That expression conveys the simple yet powerful message that European integration can only take place when both the EU institutions and the Member States respect the "rules of the game." This means, in essence, that both EU and national authorities are committed to the idea that courts-acting as independent umpires-have the final say on the question of whether those rules have been breached. Therefore, it is for courts, whether at EU or national level, to uphold the rule of law within the EU by making sure that no one is above the law.

Given that this special issue is devoted to examining the future of Europe, this Article supports the contention that the next phase of European integration must not be built on unstable foundations, but must rather be based on secure and solid values, in particular, respect for the rule of law. Since the principle of judicial independence is an essential component of the rule of law within the EU, it is only if we have strong and independent courts that European integration may continue to move on to new horizons.

In Part B., it is argued that integration through the rule of law is nothing new but has underpinned the EU since its very beginning. It is indeed the premise on which the EU system of judicial protection has been built over the years. Part C. explores - in the light of recent developments in the case law of the Court of Justice of the European Union ("Court of Justice")—what happens when that premise is called into question.

\section{B. The Rule of Law as the Law of Remedies}

More than fifty years ago, the Court of Justice famously held in Van Gend en Loos that the judicial protection of EU rights is based on a system of dual vigilance. ${ }^{1}$ In addition to the supervision carried out by the European Commission and the Member States, individuals are entitled to rely on their EU rights in the national courts. ${ }^{2}$ The enforcement of EU law is largely decentralized, in so far as the Treaties - and in particular Article 19 TEU—entrust "the responsibility for ensuring the full application of EU law in all Member States and judicial protection of the rights of individuals under that law to national courts and tribunals and to the Court of Justice." 3 Unlike in the US, there are no "EU District Courts" or "EU Courts of Appeals" in which judicial power may be

\footnotetext{
${ }^{\star}$ President of the Court of Justice of the European Union and Professor of European Union Law, Leuven University. All opinions expressed herein are personal to the author.

${ }^{1}$ Case 26/62, Van Gend en Loos v. Nederlandse Administratie der Belastingen, ECLI:EU:C:1963:1, Judgment of 5 Feb. 1963. ${ }^{2} I d$.

${ }^{3}$ See, e.g., Case C-619/18, Comm'n v. Poland (Independence of the Supreme Court), 2019 E.C.R. 531, para. 47. See also Opinion 1/09, Agreement Creating a Unified Patent Litigation System, 2011 E.C.R. 123, para. 66; Case C-583/11 P, Inuit Tapiriit Kanatami and Others v. Parliament and Council, 2013 E.C.R. 625, para. 90; Case C-456/13 P, T \& L Sugars and Sidul Açúcares v. Comm’n, 2015 E.C.R. 284, para. 45.
} 
vested both to interpret and to apply EU law. Instead, that power is shared between the EU courts and national courts. It is for the Court of Justice to say what the law of the EU is, and for national courts - as the "common law courts" of the EU—-to apply that law.

National courts have thus played a leading role in upholding the rule of law within the EU. In cooperation with the Court of Justice, they have relied on EU law in order to provide effective remedies to the rights that that law confers on individuals. By virtue of EU law, national courts have provided access to justice where national law prevented those courts from second-guessing the decisions of public authorities. ${ }^{4}$ They have set aside conflicting legal norms, including those of constitutional rank. ${ }^{5}$ They have also granted interim, declaratory, and monetary relief, even when national law failed to provide those remedies. ${ }^{6}$

In providing judicial protection, national courts may engage in a dialogue with the Court of Justice. The preliminary reference mechanism, which is the keystone of the EU system of judicial protection, ${ }^{7}$ ensures the uniform interpretation and application of EU law. That mechanism also guarantees that citizens across the EU enjoy equal protection under EU law. Since the dialogue between national courts and the Court of Justice is based on the law-and nothing but the lawaccess to the preliminary reference mechanism is only open to courts that are independent. Judicial independence is required because it guarantees that the national court referring a question to the Court of Justice will not take political considerations into account when making the reference or when implementing the Court's judgment.

Until recently, providing effective remedies was deemed sufficient in itself to secure the primacy, the unity, and the effectiveness of EU law. With effective remedies, European integration was able to move forward. The case law of the Court of Justice focused on the effectiveness of the remedies to be provided by national courts rather than on protecting the independence of the national courts providing those remedies. Academic discussions, as well as references to the Court of Justice, dealt with the complex question of how to strike the right balance between the principle of national procedural autonomy and the twin principles of equivalence and effectiveness. ${ }^{8}$ It is true that "judicial independence" has been examined by the Court of Justice in the past when a body-that did not belong to the national judiciary - sought to make a reference to that Court, as a requirement that the referring body has to meet in order to have access to the preliminary reference mechanism. ${ }^{9}$ That case law, however, did not relate to concerns that the judicial independence of a national court was in doubt.

Perhaps, given that the principle of judicial independence stems from the constitutional traditions common to the Member States as one of the founding tenets of any democratic system of governance, it was assumed that national governments would not threaten it. That principle was

\footnotetext{
${ }^{4}$ See, e.g., Case 222/84, Johnston v. Chief Constable of the Royal Ulster Constabulary, 1986 E.C.R. 206.

${ }^{5}$ See, e.g., Case C-409/06, Winner Wetten GmbH v. Bürgermeisterin der Stadt Bergheim, 2010 E.C.R. 503, para. 61 (holding that "[r]ules of national law, even of a constitutional order, cannot be allowed to undermine the unity and effectiveness of Union law"). See also Case 11/70, Internationale Handelsgesellschaft mbH v. Einfuhr- und Vorratsstelle für Getreide und Futtermittel, 1970 E.C.R. 114, para. 3.

${ }^{6}$ See Case C-213/89, The Queen v. Secretary of State for Transport, ex parte: Factortame Ltd. and others, 1990 E.C.R. 257; Case 106/77, Amministrazione delle Finanze dello Stato v. Simmenthal SpA, 1978 E.C.R. 49; Joined Cases C-46/93 \& 48/93, Brasserie du Pêcheur v. Germany, 1996 E.C.R. 79.

${ }^{7}$ Opinion 2/13, Accession of the European Union to the ECHR, 2014 E.C.R. 2454, para. 176; see also Case C-284/16, Achmea, 2018 E.C.R. 158, para. 37.

${ }^{8}$ See, e.g., Constantinos Kakouris, Do the Member States Possess Judicial Procedural Autonomy?, 34 CommON MKT. L. REV. 1389, 1389-112 (1997); Sacha Prechal, Community Law in National Courts: The Lessons from Van Schijndel, 35 CommON Mкт. L. Rev 681, 681-706 (1998); Walter van Gerven, Of Rights, Remedies and Procedures, 37 CoMmON MKT. L. REv. 501, 501-36 (2000). See also Michael Dougan, National Remedies Before the Court of Justice: Issues of Harmonisation AND DifFERENTIATION (2004).

${ }^{9}$ See, for example, Joined Cases C-110/98 to 147/98, Gabalfrisa and Others, 2000 E.C.R. 145, which is now under consideration in Case C-274/14 Banco de Santander (pending). See Opinion of Advocate General Hogan, Case C-274/14, Banco de Santander, (Sept. 24, 2019).
} 
"uncontested and incontestable." 10 It was taken as read that national governments would encourage citizens to trust the courts as the ultimate arbiters of any legal dispute, including in situations when a court ruling opposed the political majority of the day.

The motto "in the courts we trust" also applied to matters falling within the scope of EU law. The internal market could not have been built without the role played by national courts in guaranteeing the full effect of the fundamental freedoms. Since "free movers" do not, in principle, enjoy political representation in the host Member State, upholding their rights may require access to a court of law that must be able to provide effective remedies. Where those rights enter into conflict with the views of the political majority of the day, respect for the rule of law commands that majority to comply with the judgments of the courts. National courts have thus contributed to dismantling protectionist laws, either by enforcing the Treaty provisions on free movement or secondary EU law giving concrete expression to those provisions. The same findings applied in other areas of law where the EU has conferred rights on individuals. EU anti-discrimination law and EU environmental law are key examples where national courts have contributed to delivering justice.

In order to act as a check on the political majority of the day, national courts had to enjoy a series of guarantees that enabled them to operate without fear or favor. Undercutting the authority of their own courts was seen as a red line that no democratic government of a Member State would dare to cross. Any European State wishing to join the EU must adhere unequivocally to the constitutional traditions common to the Member States by ensuring compliance with democratic principles, fundamental rights, and the rule of law. As the Court of Justice made clear in the seminal Wightman and Others case, ${ }^{11}$ joining the EU-as well as leaving it—is a free and voluntary act of national sovereignty. Nonetheless, once a Member State decides to join the EU, it must comply with a set of common values. It is thus assumed that after taking up EU membership such a State will remain committed to defending liberal democracy, fundamental rights, and a government of laws, not men. Recent developments show that this assumption cannot simply be taken for granted. ${ }^{12}$

\section{Back to the Basics: EU Law as the Gatekeepers' Keeper}

National courts have operated as the "gatekeepers" of the rule of law within the EU. Despite this, as Hamilton famously wrote more than two centuries ago, ${ }^{13}$ the judiciary remains the "least dangerous branch" of government. Courts lack the power of the purse and that of the sword. It is only thanks to their independence and impartiality - as well as the quality of their reasoning - that their rulings enjoy authority and legitimacy. The question then is what should happen when the executive and/or the legislature of a Member State unduly interferes in the judicial process by undermining the independence of its own courts.

At national level, the rule of law and fundamental rights would be weakened in that scenario. Democracy would be damaged as the boundaries between law and politics become blurred. Justice would stop being a reality and would become an empty promise. At EU level, the system of effective judicial protection would be at risk because the premise on which it has been built over the last sixty years is being called into question. Integration through the rule of law could no longer take place.

\footnotetext{
${ }^{10}$ Thomas Von Danwitz, Values and the Rule of Law: Foundations of the European Union-An Inside Perspective from the ECJ, 21 Potchefstroom Electronic L.J. 1, 1-17 (2018).

${ }^{11}$ Case C-621/18, Wightman and Others, 2018 E.C.R. 999, para. 63. See also Comm'n v. Poland, Case C-619/18 at para. 42.

${ }^{12}$ See Dariusz Adamski, The Social Contract of Democratic Backsliding in the "New EU" Countries, 56 COMMON MKT. L. REV. 623, 623-66 (2019).

${ }^{13}$ See The Federalist No. 78 (Alexander Hamilton).
} 
First, since national courts that are not independent do not have access to the preliminary reference mechanism, they can no longer ensure the uniform interpretation and application of EU law, nor can citizens from across the EU enjoy equal protection of that law before those courts.

Second, courts cannot provide effective judicial protection when they are not insulated from internal and external pressure. Allowing courts that are not independent to grant remedies that are grounded in EU law does not secure judicial protection of the rights conferred by that law. It is true that a national court may, by virtue of EU law, set aside conflicting national measures and grant damages to the parties who have been adversely affected by those measures. Nevertheless, if such a court is not fully independent because the executive or the legislature may take action against it in the event that it has recourse to such remedies, there is a risk that such a court will refrain from making use of these remedies. Put simply, without judicial independence, remedies grounded in EU law become paper tigers.

Last but not least, European integration has long ago moved on from the internal market paradigm. It now seeks to establish an area of freedom, security, and justice without internal frontiers, where citizens may move freely and securely. In an area without internal frontiers, the exercise of free movement should not undermine the jurisdiction of national courts and the effectiveness of national law operating on a territorial basis. The "long arm of the law" should therefore acquire a transnational dimension, so that, for example, criminals are prevented from relying on free movement as a means of pursuing their activities with impunity. Accordingly, the authors of the EU Treaties reasoned that the free movement of persons should be accompanied by the free movement of judicial decisions. By virtue of the principle of mutual recognition, judicial decisions adopted in the Member State of origin are to be recognized and enforced in the Member State of enforcement as if they were its own.

In order for that principle to operate properly, national courts must trust that courts from other Member States are equally committed to upholding the values on which the EU is founded and, in particular, to protecting the fundamental rights of the persons concerned. As the principle of judicial independence constitutes the essence of the fundamental right to effective judicial protection, respect for that principle is of paramount importance in order to underpin the free movement of judicial decisions.

In light of the foregoing considerations, it did not come as a surprise that in the seminal Associação Sindical dos Juízes Portugueses, also known as the Portuguese Judges Case, ${ }^{14}$ the Court of Justice held that "in the fields covered by EU law," that law protects the independence of national courts. The contribution of that judgment to the development of EU law in general, and to that of the rule of law in particular, lies in the fact that it made the premise on which the entire EU system of judicial protection is built explicit-national courts, as the common law courts of the EU, must remain independent. The Court of Justice ruled that the Member States "must ensure that [national] court[s] mee[t] the requirements essential to effective judicial protection," 15 of which the principle of judicial independence is one part. This is because without the principle of judicial independence, no effective judicial protection may be provided, ${ }^{16}$ nor may the uniform interpretation and application of EU law be guaranteed. ${ }^{17}$

As an essential component of the fundamental right to effective judicial protection enshrined in Article 47 of the Charter, it is for the Court of Justice to determine-in the fields covered by EU law - the meaning and scope of the principle of judicial independence. The latter principle is thus an autonomous concept of primary EU law that draws on the constitutional traditions common to the Member States.

\footnotetext{
${ }^{14}$ Case C-64/16, Associação Sindical dos Juízes Portugueses, 2018 E.C.R. 117.

${ }^{15} \mathrm{Id}$. at para. 29.

${ }^{16} \mathrm{Id}$. at paras. $37-38$.

${ }^{17} I d$. at para. 43 .
} 
In subsequent cases, the Court of Justice has indeed clarified the meaning and scope of the principle of judicial independence. In Minister for Justice and Equality (Deficiencies in the system of justice), for example, the Court of Justice stressed the fact that the principles of judicial independence and mutual trust are deeply intertwined-national courts of different Member States will stop trusting each other if they do not exercise their judicial functions wholly autonomously. ${ }^{18}$ In that case, the Court of Justice also elevated the principle of judicial independence to the apex of EU legal norms, holding that it is part of the "essence" of the right to a fair trial enshrined in Article 47 of the Charter. ${ }^{19}$ This means that the principle of judicial independence may not be subject to limitations, regardless of the public objectives put forward by the national executive or legislature. ${ }^{20}$

Moreover, the Court of Justice has looked at the guarantees required by EU law in order for a national court to be-or to remain-independent. For instance, in Associação Sindical dos Juízes Portugueses and in Escribano Vindel, the Court of Justice held that "the receipt by [judges] of a level of remuneration commensurate with the importance of the functions they carry out constitutes a guarantee essential to the principle of judicial independence." ${ }^{21}$ In Minister for Justice and Equality (Deficiencies in the system of justice), it pointed out that in determining whether a national court is independent, one must look at rules regarding "the composition of the body and the appointment, length of service and grounds for abstention, rejection and dismissal of its members." 22 Application of these rules must then "dispel any reasonable doubt in the minds of individuals as to the imperviousness of that body to external factors and its neutrality with respect to the interests before it." ${ }^{23}$ The Court of Justice added that rules on dismissal should be determined by express legislative provisions, ${ }^{24}$ and that the disciplinary regime applicable to judges should not be used as "a system of political control of the content of judicial decisions." 25 More recently, in Commission v. Poland, the Court of Justice examined in detail the principle of irremovability from office. The Court held that this principle "requires, in particular, that judges may remain in post provided that they have not reached the obligatory retirement age or until the expiry of their mandate, where that mandate is for a fixed term." 26 The Court of Justice observed, however, that there can be legitimate and compelling grounds for removing a judge from office, insofar as those grounds comply with the principle of proportionality. It thus pointed out that "judges may be dismissed if they are deemed unfit for the purposes of carrying out their duties on account of incapacity or a serious breach of their obligations, provided the appropriate procedures are followed." 27

In examining the compatibility of those rules with the principle of judicial independence, it is worth pointing out that the Court of Justice does not seek to redesign national judiciaries, as that remains an exclusive competence of the Member States. Rather, the Court of Justice limits itself to examining whether rules that concern the organization and functioning of national courts comply with the principle of judicial independence. Those national rules are thus "circumscribed" by that fundamental principle. ${ }^{28}$

\footnotetext{
${ }^{18}$ Case C-216/18, Minister for Justice and Equality (Deficiencies in the system of justice), 2018 E.C.R. 586, paras. 58-59.

${ }^{19} I d$. at para. 48.

${ }^{20}$ Koen Lenaerts, Limits on Limitations: The Essence of Fundamental Rights in the EU, 20 GERMAN L. J. 783, 779-93 (2019).

${ }^{21}$ Associação Sindical dos Juízes Portugueses, Case C-64/16 at para. 45; Case C-49/18, Escribano Vindel, 2019 E.C.R. 106, para. 66.

${ }^{22}$ Minister for Justice and Equality, Case C-216/18 at para. 66.

${ }^{23} I d$.

${ }^{24} I d$.

${ }^{25} \mathrm{Id}$. at para. 67.

${ }^{26}$ Comm'n v. Poland, Case C-619/18 at para. 76.

${ }^{27} \mathrm{Id}$.

${ }^{28} I d$. at para. 52 .
} 


\section{Concluding Remarks}

In light of the pending cases on the rule of law, ${ }^{29}$ it is safe to say that in the near future, the Court of Justice will further clarify the guarantees that EU law requires in order for a national court to beor to remain -independent. This is a positive development because it gives the Court of Justice the opportunity to consolidate the foundations of the EU system of judicial protection. When the Court of Justice rules that a national measure is incompatible with the principle of judicial independence, it is imperative that the Member State concerned implements that Court's judgment in a faithful manner, as such implementation will bear witness of its ongoing commitment to the values on which the EU is founded. ${ }^{30}$

Today, Europeans are facing a defining moment in the history of integration. They must stand up for the values - such as democracy, the rule of law and fundamental rights - that we share in order to emphasize the point that what brings us together remains stronger than what pulls us apart. That is why the principle of judicial independence must be preserved so that the EU remains a "Union of democracies," a "Union of rights," and a "Union of justice." If the next generation of Europeans is to explore new horizons for an ever-closer Union where citizens may continue to enjoy a sphere of individual liberty free from public interferences, integration through the rule of law is the only way forward.

\footnotetext{
${ }^{29}$ To name just a few, see Case C-192/18, Comm'n v. Poland (pending); Joined Cases C-558/18 \& 563/18, Miasto Łowicz (pending); Joined Cases C-83/19, 127/19 \& 195/19, Asociația “Forumul Judecătorilor Din România” (pending); Case C-272/19 Land Hessen (pending); and Case C-564/19 IS (pending).

${ }^{30}$ The fact that Poland repealed the law that was under consideration in Commission v. Poland-before the Court of Justice ruled on that case - is a positive sign in that regard. See Case C-619/18 R, Comm'n v. Poland, 2018 E.C.R. 1021, paras. 27-31.
} 